\title{
Illegal long-line fishing and albatross extinction risk
}

\author{
Gohar A. Petrosian, Rolf A. De By and Ronald V. Clarke
}

\begin{abstract}
Birds are commonly entangled in long-line fisheries, and increases in long-line fishing activity have consistently caused declines in seabird populations. Environmental criminology would posit that the risk of such declines is greater in the case of illegal long-line fisheries, which are less likely to implement bycatch mitigation measures. To investigate this possibility we examined the overlap between data on illegal fishing and albatross at-sea occurrence ranges. Moderate correlations were found between mean exposure to illegal fishing and the Red List status of albatross species, but none were found between Red List status and total fishing pressure. A second analysis overlaid albatross at-sea occurrence ranges with long-lining data for the member countries of the Convention on Conservation of Southern Bluefin Tuna to compare the effect of exposure to legal and illegal hooks on Red List status. Lacking a better measure, Country A's hooks were used as a proxy for illegal hooks. Critically Endangered and Endangered species were 12 and 3.4 times more exposed to illegal hooks, respectively, than Near Threatened species, whereas there was no relationship between Red List status and exposure to legal hooks. Country-level analyses confirmed these findings, which provide evidence that illegal long-line fishing poses a particular threat to the survival of albatrosses. The findings suggest that the bird conservation lobby should work closely with fisheries authorities to tackle illegal fishing, and that research should identify the highest risk areas of overlap between illegal fishing and albatross at-sea ranges.
\end{abstract}

Keywords Albatross conservation, bycatch, environmental criminology, illegal fishing, long-line fishing, Red List, seabird

To view supplementary material for this article, please visit https://doi.org/10.1017/Soo3060531600o818

\section{Introduction}

$\mathrm{D}$ espite being protected under various national and international laws, albatrosses are among the most

Gohar A. Petrossian (Corresponding author) Department of Criminal Justice, John Jay College of Criminal Justice, Haaren Hall-63107, 524 West 59th Street, New York, NY 10019, USA. E-mail gpetrossian@jjay.cuny.edu

Rolf A. De By Department of Geo-information Processing, Faculty of Geoinformation Science \& Earth Observation, University of Twente, Enschede, The Netherlands

Ronald V. Clarke School of Criminal Justice, Rutgers University, Newark, USA

Received 9 May 2016. Revision requested 28 June 2016.

Accepted 20 July 2016. First published online 22 November 2016. threatened birds. Of the 22 albatross species assessed by IUCN, 17 are threatened with extinction (IUCN, 2014) by fishing, human disturbance, disease or predation by introduced species such as rats and feral cats (Croxall, 1998; Gales, 1998). The greatest of these threats is long-line fishing (Alexander et al., 1997; Gales, 1998), which increased in the 1950 when distant water fleets significantly expanded their commercial operations for tuna Thunnus spp., Patagonian toothfish Dissostichus eleginoides and related species (Tuck et al., 2003).

In long-line fishing, whether pelagic (when fishing lines are set close to the surface of the water) or demersal (when lines are set along the sea floor), several thousand baited hooks are attached to the vessel's main fishing line. This commonly results in the incidental catch, or bycatch, of non-target species (Alverson et al., 1994; Hall et al., 2000; Huang, 2011), including seabirds that strike at the baited hooks (Gales et al., 1998) and become entangled or hooked and then dragged underwater as the line sinks (Gilman, 2004). Twenty-six of the 61 species of seabirds that fall victim to long-line fishing are threatened with extinction (Gilman, 2004), including albatrosses (Anderson et al., 2011; IUCN, 2014).

Previous studies have reported the impact of long-line fishing on albatrosses and other seabird populations. One group of studies evaluated this impact globally (Gales, 1998; Nel \& Taylor, 2003; Small, 2005; Anderson et al., 2011; Huang, 2011). Another focused on specific ocean areas, such as the Southern Ocean (Tuck et al., 2003) and Inter-American Tropical Tuna Commission management area (Anderson, 2009), or specific islands and countries (Croxall \& Prince, 1996; Brothers et al., 1998; Gales et al., 1998; Prince et al., 1998; Arnold et al., 2006; Gandini \& Frere, 2006; Petersen et al., 2007). A third group of studies examined the impact of long-line fishing on specific albatross species, such as the Amsterdam albatross Diomedea amsterdamensis (Weimerskirch et al., 1997), wandering albatross Diomedea exulans (Croxall \& Prince, 1996), shy albatross Thalassarche cauta (Brothers et al., 1998) and black-browed albatross Thalassarche melanophris (Arnold et al., 2006; Petersen et al., 2007).

This body of research has established that long-line fishing has a significant impact on albatrosses. Furthermore, it has been concluded that long-line fishing constitutes a threat greater than any other to the viability of albatrosses (Alexander et al., 1997; Gales, 1998), and our preliminary work for this study using BirdLife International (2014) albatross fact-sheets supported this conclusion. According to the fact-sheets 20 albatross species are significantly affected by fishing, and 16 are affected by the next most common 
threat, invasive species such as rats and feral cats, which eat the eggs and chicks of albatrosses on islands where they breed. However, fisheries and invasive species are not equivalent in their likely impact. It is not difficult to see how all species of albatrosses could be affected by fisheries encountered in their ranges (although these encounters need to be specified in more detail) but it is less easy to see how all albatrosses could be threatened by invasive species. This is because the threat of invasive species is more complex: albatrosses breed widely over 284 islands (del Hoyo et al., 1992; BirdLife International, 2014; Avibase, 2015; Gill \& Donsker, 2015; Xeno-canto, 2015) but 90\% (256) of these islands host only one or two species of albatrosses, and where invasive species threaten albatrosses these are typically cases of one island, with one or two invasive species. Thus, some species could be decimated by invasive species on particular islands; however, the incapability of invasive species to reach other widely scattered and remote islands without human assistance makes it less likely that they could threaten the existence of multiple species of albatrosses. In the case of long-line fishing, albatrosses are naturally exposed to this threat by ranging widely at sea.

Whatever the merits of the argument, there is little relationship between the number of breeding islands and IUCN Red List status of albatrosses. For the three Critically Endangered species the median number of breeding islands is two, for the four Endangered species it is 13, for the 10 Vulnerable species it is four, and for the five Near Threatened species it is two $(\mathrm{H}(3)=2.13, \mathrm{P}>0.05)$. The findings about the importance of long-line fishing in the extinction risk of albatrosses attracted our interest as criminologists because much long-line fishing is known to be illegal. It has been estimated that illegal fishing for Patagonian toothfish alone kills c. 145,00o seabirds annually (Thomas, 2000), and this impact is unknown but potentially high in other fisheries around the globe ( $\mathrm{Nel}$ et al., 2002; Sumaila et al., 2006). Consistent with theories of environmental criminology that guide our work, we would expect that illegal long-line fishers have a greater impact, proportionate to their fewer numbers, on albatross populations than their legal counterparts. This is because illegal fishers, who have already shown themselves to be prepared to flout the law, are less likely to conform to advisory bycatch mitigation measures, such as night (instead of day) setting, underwater settings, bird-scaring devices, thawed baits and line weighting. That these measures have generally been found to be effective (e.g. Gilman et al., 2003; Løkkeborg, 2003; Jiménez et al., 2009; Melvin et al., 2010) may be of little importance to illegal fishers, who are likely to avoid them because of the costs and inconvenience involved.

Although several studies have attempted to estimate the bycatch of seabirds in illegal fisheries (e.g. Tuck et al., 2003;
Anderson et al., 2011) and have raised concerns about the impact of these fisheries on albatrosses, the contribution of illegal fishing to the extinction risk of albatrosses had not previously been empirically tested. We investigated (1) whether illegal fishing presents a significant threat to albatrosses and (2) whether it is illegal long-line fishing in particular that presents the threat.

\section{Theoretical background: environmental criminology}

This study draws on environmental criminology, which seeks to explain the interaction between motivated offenders and the opportunity structures within their environments that make specific crimes possible. The ultimate purpose of such analysis is to identify ways to reduce the opportunities for those kinds of crimes by increasing their difficulties and risks, reducing their rewards and minimizing associated temptations, provocations and excuses. Environmental criminology has guided the study of other wildlife crimes, including poaching of African elephants Loxodonta africana (Lemieux \& Clarke, 2009), tigers Panthera tigris in Indian reserves (Clarke et al., 2015; Kim et al., 2015) and parrots in the Neotropics (Pires \& Clarke, 2011, 2012; Clarke \& de By, 2013). These studies have employed a range of analytical techniques, including overlaying maps of data collected by biologists and conservation scientists, to examine the facilitating conditions that give rise to these crimes. A general finding of environmental criminology (to which we return when discussing future research) is that problems are more concentrated than generally thought, and that preventive efforts should therefore be similarly focused.

Environmental criminology would predict that illegal fishers will choose to fish where the most commercially valuable species are to be found (Petrossian \& Clarke, 2014), as well as where monitoring and control of waters is weak or minimal (Petrossian, 2015). These facilitating conditions increase the offenders' perceptions of potential rewards and reduce their fear of being caught. Having chosen where to fish, they must then make a sequence of further decisions, including when to fish, where and when to offload their catches and where to fish next. The need to avoid detection and the resulting complications are important in all these decisions. Perhaps the easiest decision to predict is that illegal fishers would not implement bycatch mitigation measures that would be of little help in evading detection.

\section{Methods}

The first analysis examined whether a species' IUCN Red List status was related to its exposure to illegal fishing; the second analysis examined whether a species' IUCN Red List status was related to its exposure to illegal long-line 
TABLE 1 Data sources and types of data used in the analysis of illegal long-line fishing and albatross extinction risk.

\begin{tabular}{lll}
\hline Data & Data source & $\begin{array}{l}\text { Applied to } \\
\text { research } \\
\text { questions }\end{array}$ \\
\hline $\begin{array}{l}\text { Albatross threatened } \\
\text { status }\end{array}$ & IUCN (2014) & $1 \& 2$ \\
$\begin{array}{l}\text { Albatross at-sea } \\
\text { occurrence ranges }\end{array}$ & $\begin{array}{l}\text { BirdLife International } \\
\text { Illegal fishing estimates } \\
\text { for FAO fishing regions }\end{array}$ & Agnew et al. (2009) \\
$\begin{array}{l}\text { Reconstructed catches for } \\
\begin{array}{l}\text { 2003 } \\
\text { Country scores on illegal } \\
\text { fishing \& compliance } \\
\text { with bycatch mitigation } \\
\text { measures }\end{array}\end{array}$ & $\begin{array}{l}\text { Sea Around Us Project } \\
\text { Pitcher et al. (2006) }\end{array}$ & 1 \\
$\begin{array}{l}\text { Long-line fishing catch \& } \\
\text { effort }\end{array}$ & $\begin{array}{l}\text { Commission for the } \\
\text { Conservation of }\end{array}$ & 2 \\
\hline
\end{tabular}

hooks. The data sources, types of data and the research questions these data were used to answer are presented in Table 1.

The dependent variable 'extinction risk of albatrosses' was conceptualized in terms of the IUCN conservation status of each species of albatross. The 22 albatross species fell under four IUCN status rankings in 2014: Critically Endangered, Endangered, Vulnerable and Near Threatened. These were coded 1-4, with the highest score assigned to Critically Endangered.

\section{Research question 1: Is a species' IUCN Red List status related to its exposure to illegal fishing?}

Approach and data Answering this question required us to undertake two analyses examining the correlations between IUCN Red List status and illegal fishing, and IUCN Red List status and total fishing pressure. In the first analysis we used global estimates of illegal fishing that were obtained by analysing data for 54 exclusive economic zones and 15 high seas regions (Agnew et al., 2009). Agnew et al. (2009) aggregated the data into the United Nations Food and Agriculture Organization (FAO) fishing areas, and reported 5-year estimates for 15 of these areas. For each area they provided a percentage estimate of illegal fishing averaged in 5-year increments for 1980-1999, and for 2000-2003. We used the most recent estimates, for 20002003 (e.g. 32\% for the South-west Atlantic (Area 41) and $3 \%$ for the North-east Pacific (Area 67); Fig. 1). The FAO Yearbook of Fishery Statistics (2003) report was used to gather data on catches by FAO fishing area.
Analysis We used the object-relational database management system PostgreSQL v. 9.4.4 (The PostgreSQL Global Development Group, University of California, Berkeley, USA) with the PostGIS v. 2.2.o spatial extension to overlay several datasets. We used the FAO illegal fishing estimates averaged for 2000-2003 (Agnew et al., 2009) and albatross at-sea occurrence range (BirdLife International, 2014) datasets to examine the extent to which albatrosses are exposed to illegal fishing. We calculated the weighted percentage overlap with each of these FAO areas, thus estimating the weighted exposure percentage, $\operatorname{WEP}(s)$, for any species $s$. To weight the exposure to illegal fishing against total fishing pressure in these regions we also calculated the weighted percentage overlap with each of these $\mathrm{FAO}$ areas. We used reconstructed catch data (in tons in 2003) by FAO fishing area (Pauly \& Zeller, 2015) and standardized these by dividing the catch data by the size of the FAO fishing area. We then overlaid this dataset with albatross at-sea occurrence ranges (BirdLife International, 2014) to calculate the weighted exposure percentage to all fishing in these regions. We calculated the weighted exposure percentage for an albatross species $s$ as follows. Range(s) denotes the geographical range of species $s$. If regions is the set of high seas regions recognized by $\mathrm{FAO}$, then for any of its members, $r$, range $(r)$ denotes the geographical range of region $r$. IF $(r)$ denotes $r$ the recorded percentage of illegal fishing in $r$ during 2000-2003. For any geography $g$, area $(g)$ denotes the geography's area in $\mathrm{km}^{2}$. To determine how much a region contributes to the illegal fishing exposure suffered by a species, we use the ratio between the species' at-sea range within the region and its at-sea range globally. This ratio is denoted by $\operatorname{SZR}(r, s)$ and is defined as:

$$
\operatorname{SZR}(r, s)=\frac{\operatorname{area}(\text { intersection }(\operatorname{range}(r), \operatorname{range}(s)))}{\operatorname{area}(\operatorname{range}(s))}
$$

The weighted exposure percentage is defined as follows:

$$
W E P(s)=\sum_{r \in \text { regions }} I F(r) \cdot \operatorname{SZR}(r, s)
$$

For weighted exposure percentage calculations for total fishing pressure, we replaced $I F(r)$ with catch in tons per FAO fishing area in 2003.

\section{Research question 2: Is a species' IUCN Red List status related to its exposure to illegal long-line hooks?}

Approach and data To answer this question we undertook two analyses of hook data, the mean differences between illegal hooks and total legal hooks, and those between all 


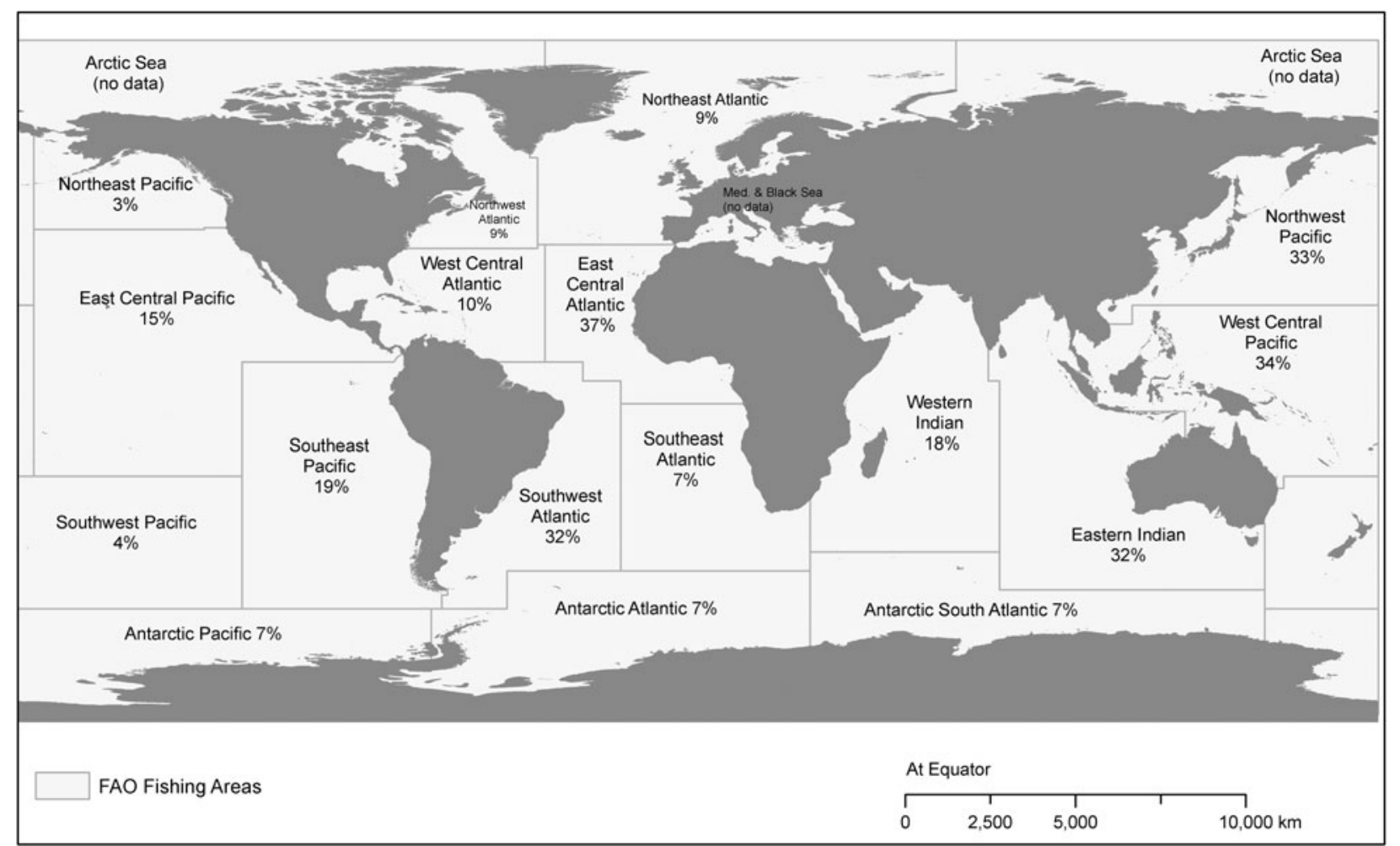

Fig. 1 Regional estimates of illegal fishing by FAO fishing area, 2000-2003 (source: Agnew et al., 2009).

legal hooks separated by country. The first analysis followed previous researchers (e.g. Klaer et al., 2009) who examined seabird bycatch by using data on total fishing effort reported to the International Commission for the Conservation of Atlantic Tunas (at $5 \times 5^{\circ}$ longitude/latitude cell resolution). We obtained data on long-line fishing catch and effort (measured as number of hooks) for 1992-2012 from the Commission for the Conservation of Southern Bluefin Tuna, a regional fisheries management organization responsible for collecting and managing catch and effort data for its member countries (Australia, Japan, New Zealand, South Africa, South Korea and Taiwan). We used these data because (1) the Commission is the only organization whose convention area overlaps with 17 of 22 (considering the white-capped albatross Thalassarche steadi as a subspecies of Thalassarche cauta) albatross at-sea occurrence ranges (excluded are short-tailed Phoebastria albatrus, Laysan Phoebastria immutabilis, black-footed Phoebastria nigripes and waved albatrosses Phoebastria irrorata), and (2) it is one of the few regional fisheries management organizations that has publicly available long-line fishing catch and effort data. We converted these catch and effort data into a geographical information system (GIS) data file and overlaid it with at-sea occurrence ranges of 17 albatross species that fall within the convention area of the Commission for the Conservation of Southern Bluefin Tuna (Fig. 2). Rather than identify the
Commission's member countries in this analysis we chose to designate them by letters, as to name them could divert attention from our intended focus (i.e. the relationship between illegal fishing and albatross extinction risk) to that of blaming the worst offending country (i.e. Country A). The information on illegal long-lining came from a study by Pitcher et al. (2006) that included 54 country-specific reports amounting to 1,170 pages of information, and which took a research team 3 years to complete. Their report assessed the compliance of 54 countries with the FAO's Code of Conduct for Responsible Fisheries (FAO, 1995) using 44 questions. The study and reports were based on 2,332 separate analyses and reviewed $>2,400$ reference materials, including international treaties, country synopses, fisheries agency reports, national legislation, and published and grey literature. In addition to internal validation procedures, the research team also consulted external experts for 33 of the 54 countries to verify their assessment scores (Pitcher et al., 2006).

Three questions from these reports were particularly relevant to our research, of which one assessed a country's involvement in illegal fishing and two examined a country's compliance with bycatch mitigation measures. The researchers scored countries on a scale of $0-10$ to indicate the degree to which each country was involved in illegal fishing: 0 , not involved in illegal fishing; 2.5, occasionally involved; 5 , often involved; 7.5, involved half as much as in 


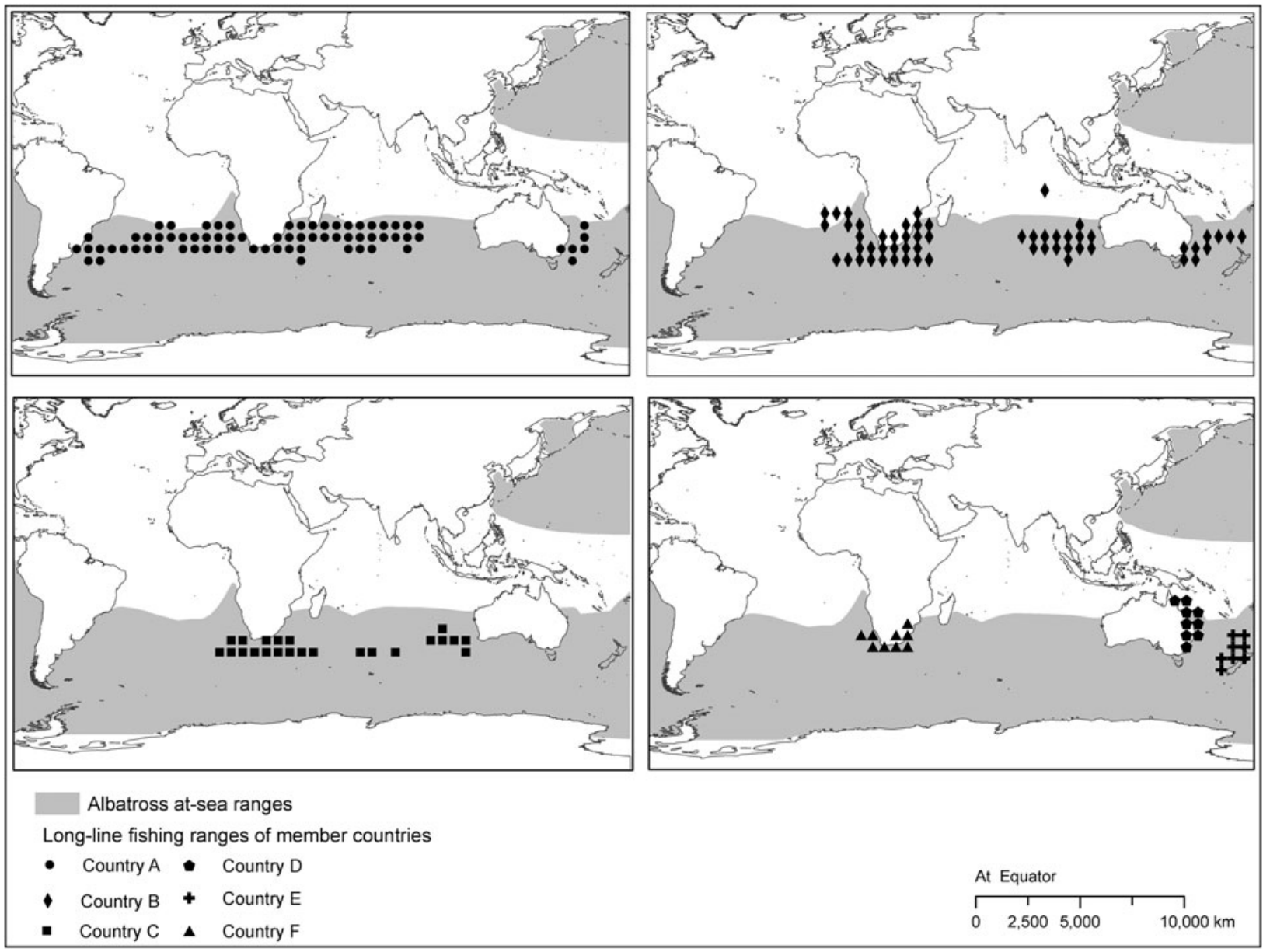

FIG. 2 Long-line fishing ranges in 2012 of member countries of the Commission for the Conservation of Southern Bluefin Tuna.

legal fishing; 10, involved almost as much as or more than in legal fishing. The two questions on bycatch mitigation measures were (1) Are fishing methods known to be harmful to habitats or to create bycatch problems, or whose high fishing capacity is difficult to control, being phased out? and (2) Is fishing gear mandated by a management plan to avoid bycatch of non-target species, and environmental and habitat damage? The researchers scored countries on a scale of o-10 (o being worst, and 10 best) to indicate their performance on these measures.

We used the information from these reports to group member countries of the Commission for the Conservation of Southern Bluefin Tuna. Among these countries, Country A had the highest illegal fishing score (9.5 out of 10), and the lowest mean score (1.5 out of 10 ) on the two bycatch mitigation measures. Other member countries had low scores on the degree of illegal fishing (mean score of 4.8 out of 10), and average scores on questions measuring bycatch mitigation effort (mean score of 4.7 out of 10). Catch and effort data for Country A were therefore used to measure the degree to which albatrosses are exposed to illegal long-line fishing, and the total catch and effort data from the remaining countries were used to conceptualize other (legal) long-line fishing effort. Instead of treating all catch and effort data of these countries as $100 \%$ legal or illegal we weighted these numbers using the illegal fishing scores assigned by Pitcher et al. (2006). Thus, for example, Country A's illegal fishing score was 9.5 out of 10 , and therefore we treated $95 \%$ of the country's hooks as illegal. Similarly, Country D's illegal fishing score was 2.5 out of 10 , and therefore we treated only $75 \%$ of the country's hooks as legal. The long-line fishing efforts of member countries are illustrated in Fig. 2.

Analysis To compute albatross exposure to hooks we used GIS software in combination with two data sources: annual effort data on long-line hooks, per country of vessel origin and per at-sea location (CCSBT, 2012), and albatross at-sea occurrence ranges (BirdLife International, 2014). We used these data to determine the total exposure, per species, to both legal and illegal hooks, calculated in terms of density of hook setting, for all albatross species. We developed two notions of hook density for any species $s$ and year $y$ : legal_hook_density $(s, y)$ and illegal_hook_density $(s, y)$.

The annual effort data consisted of country, year, location, and records of hooks set. The number of hooks set 
by any given country in a given year at a given location was determined. We used data from 1992 onwards, as we found inconsistencies in the data for earlier years. The data thus comprised c. 20,000 records, involving c. 3.5 billion hooks aggregated over the years. The location of each record is given as a point on a regular longitude/latitude grid at $5^{\circ}$ distance; thus a record is interpreted as representing a region of $5 \times 5^{\circ}$ longitude/latitude with that point as midpoint. These regions are called cregions. For any such region $c$ and species $s$ the above formula for $S Z R$ can be used to determine the fraction of a species' at-sea range within region $c$ as $S Z R(c$, $s)$. The function hooks_exposed ${ }_{\text {illegal }}(s, y)$ gives the total number of illegal hooks to which species $s$ was exposed in year $y$ :

$$
\text { hooks_exposed }_{\text {illegal }}(s, y)=\sum_{\begin{array}{c}
c \in \text { cregions } \\
\text { country }=\text { Country } A
\end{array}} \text { hooks }(\text { country, } y, c) \cdot \operatorname{SZR}(c, s)
$$

Analogously, hooks_exposed $d_{\text {legal }}(s, y)$ defines the total number of legal hooks:

$$
\text { hooks_exposed }_{\text {legal }}(s, y)=\sum_{\substack{c \in \text { cregions } \\ \text { country } \neq \text { Country } A}} \text { hooks }(\text { country, } y, c) \cdot \operatorname{SZR}(c, s)
$$

These formulas are expanded to provide illegal (or legal) hook density per species per year, as follows:

$$
h_{o o k s \_d e n s i t y} \text { illegal }(s, y)=\frac{\text { hooks_exposed }_{\text {illegal }}(s, y)}{\operatorname{area}(\operatorname{range}(s))}
$$

\section{Results}

\section{Research question 1}

Spearman's $\rho$ analysis indicated a positive and moderate correlation (Cohen, 1988) between a species' IUCN Red List status and its weighted percentage exposure to illegal fishing during 2000-2003 ( $\rho=0.38, \mathrm{P}<0.05, \mathrm{n}=22$ ). We found similar results for other periods (e.g. for 1985-1989, $\rho=0.48, \mathrm{P}<0.05$ ). The weighted percentage exposure to illegal fishing has been relatively consistent for albatross species since 1980 (Agnew et al., 2009), whereas the IUCN Red List status of all albatrosses except for the Chatham Thalassarche eremita and Buller's albatrosses Thalassarche bulleri has continued to decline. This suggests that the effect of illegal fishing has been cumulative over time (see IUCN Red List status and Illegal fishing \% overlap columns in Supplementary Table $\mathrm{S}_{1}$ ).

When examining the exposure of albatrosses to overall fishing pressure, the negative value of the correlation coefficient indicated that species with a high threat status on the IUCN Red List were exposed to lower fishing pressures; however, these results were not statistically significant $(\rho=-0.04, \mathrm{P}>0.05, \mathrm{n}=22)$.

\section{Research question 2}

We found that the higher a species' exposure to hooks, the higher its Red List status (Table 2). Critically Endangered and Endangered species were $\mathbf{1 2 . 1 5}$ and 3.34 times more exposed to Country A (illegal) hooks, respectively, than Near Threatened species. We used an analysis of variance test to examine the overall mean differences between these groups in their exposure to both legal and illegal hooks. We found no significant differences in exposure to legal hooks $\left(F(3,16)=0.99, \mathrm{P}>0.05, \omega^{2}=0.01\right)$, whereas the difference between the four groups and the species' mean exposure to illegal (Country A) hooks was statistically significant, with a large effect (Kirk, 1996; $\left.F(3,16)=8.90, \mathrm{P}<0.01, \omega^{2}=0.58\right)$.

We conducted country-level analyses to complement these findings and to further explore the exposure of albatross species to legal hooks. The analyses revealed no significant differences between the species groups for four of the five countries (Country B: $F(3,16)=1.83, \mathrm{P}>0.05, \omega^{2}=0.13$; Country D: $F(3,16)=0.76, \mathrm{P}>0.05, \omega^{2}=0.04$; Country E: $F$ $(3,16)=2.11, \mathrm{P}>0.05, \omega^{2}=0.16$; Country $\mathrm{F}: F(3,16)=1.81$, $\left.\mathrm{P}>0.05, \omega^{2}=0.00\right)$. For Country $\mathrm{C}$ the differences were significant $\left(F(3,16)=4.95, \mathrm{P}<0.05, \omega^{2}=0.41\right)$; however, considering the mean exposure to Country $C$ hooks is 0.42 per $\mathrm{km}^{2}$ for Critically Endangered species, which is less than that for other groups, this difference is not substantively significant. Of the five countries, Country B sets significantly more hooks than the other countries (e.g. Critically Endangered species are exposed to 19.41 times more Country B hooks than the legal hooks of the other four countries combined, but the exposure of albatrosses to Country B hooks was not significantly different when albatrosses in different threat categories were compared. Therefore, it is the exposure to Country A hooks (i.e. those we conceptualized as illegal hooks) that significantly affects albatrosses.

\section{Discussion}

\section{Summary of findings}

This study is the first to examine the relationship between illegal fishing and albatross extinction risk. In doing so we undertook two analyses to examine how illegal fishing affects albatross populations. The first analysis examined the differences in species' exposure to illegal fishing and their IUCN Red List status. The results showed that a higher category of threat was significantly associated with exposure to illegal fishing. Moreover, this effect has been cumulative over time. We found no correlations between overall exposure to fishing pressure and IUCN Red List status. 
TABLE 2 Mean exposure to long-line hooks of 17 albatross species categorized as Critically Endangered, Endangered, Vulnerable or Near Threatened on the IUCN Red List, whose at-sea ranges overlap with the Commission for the Conservation of Southern Bluefin Tuna convention area.

\begin{tabular}{|c|c|c|c|c|c|c|c|}
\hline \multirow{2}{*}{$\begin{array}{l}\text { Red List status } \\
\text { (no. of species) }\end{array}$} & \multicolumn{6}{|c|}{ Exposure to legal hooks $\mathrm{km}^{-2}$ (mean $\left.\pm \mathrm{SD}\right)$} & \multirow{2}{*}{$\begin{array}{l}\text { Exposure to Country A } \\
\text { (illegal) hooks } \mathrm{km}^{-2} \\
(\text { mean } \pm \mathrm{SD})\end{array}$} \\
\hline & Country B & Country C & Country D & Country E & Country F & Total & \\
\hline Critically Endangered (2) & $8.54 \pm 4.76$ & $0.42 \pm 0.05$ & $0.00 \pm 0.00$ & $0.00 \pm 0.00$ & $0.02 \pm 0.03$ & $8.98 \pm 4.84$ & $44.12 \pm 30.87$ \\
\hline Endangered (5) & $7.92 \pm 4.60$ & $0.28 \pm 0.14$ & $0.49 \pm 0.51$ & $0.33 \pm 0.35$ & $0.01 \pm 0.01$ & $9.02 \pm 5.28$ & $12.14 \pm 7.72$ \\
\hline Vulnerable (7) & $4.25 \pm 2.22$ & $0.13 \pm 0.12$ & $0.57 \pm 0.52$ & $0.79 \pm 0.42$ & $0.00 \pm 0.00$ & $5.73 \pm 2.82$ & $3.17 \pm 3.94$ \\
\hline Near Threatened (3) & $3.56 \pm 3.66$ & $0.07 \pm 0.12$ & $0.54 \pm 0.41$ & $0.92 \pm 0.96$ & $0.00 \pm 0.00$ & $5.09 \pm 4.30$ & $3.63 \pm 6.11$ \\
\hline
\end{tabular}

${ }^{*}$ Country A hooks were used as a proxy measure for illegal hooks.

The second analysis examined the impact of exposure to illegal long-line hooks. Using Country A hooks as a proxy measure of illegal hooks we found that Critically Endangered and Endangered species were 12 and 3.4 times more exposed to these hooks, respectively, than Near Threatened species. Species' exposure to legal hooks was not significantly related to their Red List status.

\section{Limitations and future research}

This study suffered from some limitations. The most important of these was that we could find no data on illegal long-line fishing within the albatross ranges, and found it necessary to use instead a proxy measure: data for Country A's long-line fishing catch and effort. This assumption was grounded on Pitcher et al. (2006) and their detailed findings from separate country reports. Their scoring of Country A as one of the worst performing countries among the 54 that they studied was not only based on these analyses but was also verified by external country experts. In addition, we found that among the Commission for the Conservation of Southern Bluefin Tuna member countries, Country A obtained the lowest mean scores (1.5 out of 10) on the two bycatch mitigation measures of Pitcher et al. (2006). Furthermore, in a detailed analysis of the member countries, we found that it was exposure to Country A hooks, and no others, that significantly affected albatrosses. We therefore remain confident that, in the context of this study, our proxy measure of illegal fishing was appropriate. Should a new source of data specifically on illegal long-line fishing become available it would be important to analyse albatross extinction risk in light of that new information.

We also found it necessary to use the IUCN Red List status of albatross species as a proxy measure of species' extinction risk. Although albatross population estimates would be a better measure, complete estimates were only available for 2014. The availability of reliable population estimates from the same time periods would have facilitated more accurate analyses. If complete data on albatross population trends were available it would be possible to conduct analyses of albatross' exposure to illegal fishing for the same 5-year increments (during 1980-2003) that Agnew et al. (2009) used to estimate illegal fishing in $\mathrm{FAO}$ fishing areas.

Our use of albatross at-sea occurrence ranges may not necessarily reflect at-sea densities of these species, which vary over time as annual migration patterns unfold (Weimerskirch et al., 2015). Data on at-sea densities are not readily available but could potentially be derived or modelled from telemetric data on albatrosses in the nonbreeding seasons. Dynamic population models can be constructed to show dispersal of birds at sea as the season progresses (Žydelis et al., 2011). These patterns and how they differ per population and per sex are only beginning to be understood (Weimerskirch et al., 2015). Once such data become available for all albatross species, this study could be repeated using these dynamic models instead of at-sea occurrence ranges.

Our study did not differentiate between species' ranges during breeding and non-breeding seasons, nor did it account for temporal differences. Considering Commission for the Conservation of Southern Bluefin Tuna long-lining catch and effort data are available at the $5 \times 5^{\circ}$ grid cell level and by month, telemetric data could be combined with these long-lining data to pinpoint not only the riskiest activity spaces (Brantingham \& Brantingham, 1993) where albatrosses are most vulnerable to bycatch but also the seasons when this risk of exposure is significantly intensified. Further work on these spatial and temporal concentrations would require a considerable effort outside the scope of the current research.

\section{Policy implications}

Despite the limitations of the data, we believe that our study has provided evidence that illegal fishing is an important contributor to the extinction risk of albatrosses. Illegal fishing has broader implications than its threat to albatrosses, yet decades of international efforts have made little progress in dealing with that larger problem. The reasons lie beyond the reach of this paper but perhaps there is some scope for 
reducing illegal fishing where it overlaps with albatross at-sea ranges. This could be accomplished through a greater collaborative effort between the bird conservation lobby and fisheries management authorities to raise awareness about the effect of illegal fishing on albatross extinction risk, as well as to devise possible solutions. For example, a partnership could be built between BirdLife International and the International Monitoring, Control and Surveillance Network, which facilitates communication between various fisheries enforcement agencies worldwide. These two organizations could raise awareness about areas where estimated levels of illegal fishing activity are high and where these areas overlap with albatross at-sea occurrence ranges.

In areas where the exposure of albatrosses to illegal fishing is high, more rigorous mitigation measures should, where possible, be put in place. This could be accomplished, for example, by creating an international conservation organization with law enforcement powers afforded through the United Nations World Charter for Nature (such as those of the Sea Shepherd Conservation Society, which has had many successes in intercepting, intimidating and reporting illegal fishing vessels to relevant enforcement authorities), which could monitor vulnerable areas. Meanwhile, the Commission for the Conservation of Southern Bluefin Tuna should be ever more watchful of the operations of illegal fishing vessels. Although it does not have any direct enforcement capacity in international waters, the Commission could utilize its regulatory powers on trade restrictions and blacklisting of illegal fishing vessels to watch more closely the operations of these vessels in its management area. Future violations could come with further stipulations that restrict the member or non-member cooperating states from fishing within the organization's convention area for a certain period of time.

The Commission for the Conservation of Southern Bluefin Tuna and other fishing authorities are responsible for patrolling vast swathes of ocean and their task could be assisted by more detailed statistical analyses of the exposure of albatrosses to long-lining hooks, which is known to differ significantly across seasons and times of the day (e.g. on the South Georgia continental shelf albatrosses are most vulnerable to long-line bycatch during the chickbrooding period, when adult birds of both sexes spend time foraging in areas where long-line fisheries operate). There is a low risk of interaction with these fisheries during the incubation period (December-February) and during the chick-rearing period (late May-October) (Croxall \& Prince, 1996). In addition, the probability of seabirds being killed is highest during the day (Gales et al., 1998) and increases with water depth (the most important predictor for petrels) and during brighter nights (most important for albatrosses; Gandini \& Frere, 2006). Future research should explore these patterns of concentration to guide more targeted response strategies. Restrictions on fishing activities could then be better able to take account of the seasonal and temporal behaviours of albatrosses to reduce their exposure to fishing. Consistent with a core finding of environmental criminology, crime is not randomly distributed but instead is highly concentrated in particular places and at particular times. Given the considerable overlap between albatross at-sea ranges, several albatross species could benefit simultaneously from the identification and monitoring of small high-risk areas. Identifying these areas more precisely could be of considerable assistance in the implementation of effective and practical measures for protecting albatrosses from illegal fishing and would be a valuable use of scarce research resources.

\section{Author contributions}

GP contributed to the conception and writing of the article and conducted the analyses. RdB conducted the spatial computations and contributed to the writing of the article. RVC contributed to the conception and writing of the article.

\section{References}

Agnew, D.J., Pearce, J., Pramod, G., Peatman, T., Watson, R., Beddington, J.R. \& Pitcher, T.J. (2009) Estimating the worldwide extent of illegal fishing. PLoS ONE, 4(2), e4570.

Alexander, K., Robertson, G. \& Gales, R. (1997) The Incidental Mortality of Albatrosses in Long-line Fisheries: A Report on the Workshop from the First International Conference on the Biology and Conservation of Albatrosses, Hobart, Australia, September 1995. Australian Antarctic Division, Kingston, Australia.

Alverson, D.L., Freeberg, M.H., Murawaski, S.A. \& Pope, J.G. (1994) A Global Assessment of Fisheries Bycatch and Discards. FAO Fisheries Technical Paper No. 339. Food and Agriculture Organization of the United Nations, Rome, Italy.

Anderson, O. (2009) Estimating Seabird Bycatch Rates in IATTC Industrial Longline Fisheries. BirdLife International, Global Seabird Programme, RSPB, Sandy, UK.

Anderson, O.R.J., Small, C.J., Croxall, J.P., Dunn, E.K., Sullivan, B.J., YATEs, O. \& BlACK, A. (2011) Global seabird bycatch in longline fisheries. Endangered Species Research, 14, 91-106.

Arnold, J.M., Brault, S. \& Croxall, J.P. (2006) Albatross populations in peril: a population trajectory for black-browed albatrosses at South Georgia. Ecological Applications, 16, 419-432.

Avibase (2015) The world bird database. Http://avibase.bsc-eoc.org/ avibase.jsp?lang=EN [accessed January 2015].

Birdife International (2014) Species factsheets. Http://www. birdlife.org/datazone/species [accessed September 2014].

Brantingham, P.L. \& Brantingham, P.J. (1993) Environment, routine and situation: toward a pattern theory of crime. Advances in Criminological Theory, 5, 259-294.

Brothers, N., Gales, R., Hedd, A. \& Robertson, G. (1998) Foraging movements of the shy albatross Diomedea cauta breeding in Australia; implications for interactions with longline fisheries. Ibis, 140, 446-457.

Clarke, R.V. \& De By, R.A. (2013) Poaching, habitat loss and the decline of neotropical parrots: a comparative spatial analysis. Journal of Experimental Criminology, 9, 333-353.

Clarke, R.V., Chetty, K. \& Natarajan, M. (2015) Eyes on the forest: CCTV and ecotourism in Indian tiger reserves. In Situational 
Prevention of Poaching (ed. A. M. Lemieux), pp. 177-200. Routledge, New York, USA.

Cohen, J. (1988) Statistical Power Analysis for the Behavioral Sciences. 2nd edition. Lawrence Erlbaum Associates, Mahwah, USA.

CCSBT (Commission for the Conservation of Southern Bluefin Tuna) (2012) Longline fishery catch and effort data. Https://www.ccsbt.org/en/content/sbt-data [accessed October 2013].

Croxall, J.P. (1998) Research and conservation: a future for albatrosses? In Albatross Biology and Conservation (eds R. Robertson \& R. Gales), pp. 269-29o. Surrey Beatty and Sons, Chipping Norton, Australia.

Croxall, J.P. \& Prince, P.A. (1996) Potential interactions between wandering albatrosses and longline fisheries for Patagonian toothfish at South Georgia. CCAMLR Science, 3, 101-110.

Del Hoyo, J., Elliott, A. \& Sargatal, J. (eds) (1992) Handbook of the Birds of the World. Volume 1. Lynx Edicions, Barcelona, Spain.

FAO (Food and Agriculture Organization of the United NAtions) (1995) FAO Code of Conduct for Responsible Fisheries. FAO, Rome, Italy.

FAO (Food and Agriculture Organization of the United NATions) (2008) FAO Yearbook. Fishery and Aquaculture Statistics. FAO, Rome, Italy.

Gales, R. (1998) Albatross populations: status and threats. In Albatross Biology and Conservation (eds R. Robertson \& R. Gales), pp. 20-45. Surrey Beatty and Sons, Chipping Norton, Australia.

Gales, R., Brothers, N. \& Reid, T. (1998) Seabird mortality in the Japanese tuna longline fishery around Australia, 1988-1995. Biological Conservation, 86, 37-56.

Gandini, P. \& Frere, E. (2006) Spatial and temporal patterns in the bycatch of seabirds in the Argentinian longline fishery. Fishery Bulletin, 104, 482-485.

Gill, F. \& Donsker, D. (eds) (2015) IOC World Bird List. Version 5.1. Http://www.worldbirdnames.org/ [accessed January 2015].

Gilman, E. (2004) References on Seabird Bycatch in Longline Fisheries. Blue Ocean Institute, Honolulu, USA

Gilman, E., Boggs, C. \& Brothers, N. (2003) Performance assessment of an underwater setting chute to mitigate seabird bycatch in the Hawaii pelagic longline tuna fishery. Ocean \& Coastal Management, 46, 985-1010.

Hall, M.A., Alverson, D.L. \& Metuzals, K.I. (200o) By-catch: problems and solutions. Marine Pollution Bulletin, 41, 204-219.

HUANG, H.-W. (2011) Bycatch of high sea longline fisheries and measures taken by Taiwan: actions and challenges. Marine Policy, $35,712-720$

IUCN (2014) IUCN Red List of Threatened Species v. 2014.2. Http:// www.iucnredlist.org [accessed March 2014].

Jiménez, S., Domingo, A. \& Brazeiro, A. (2009) Seabird bycatch in the Southwest Atlantic: interaction with the Uruguayan pelagic longline fishery. Polar Biology, 32, 187-196.

Kim, J.H., Clarke, R.V. \& Miller, J. (2015) Poaching and tiger populations in Indian reserves: useful outcomes of a failed risky facilities analysis. In Situational Prevention of Poaching (ed. A.M. Lemieux), pp. 154-176. Routledge, New York, USA.

KIRK, R.E. (1996) Practical significance: a concept whose time has come. Educational and Psychological Measurement, 56, 746-759.

Klaer, N.L., Black, A. \& Howgate, E. (2009) Preliminary estimates of total seabird bycatch by ICCAT fisheries in recent years. ICCAT, $64,2405-2414$.

Lemieux, A.M. \& Clarke, R.V. (2009) The international ban on ivory sales and its effects on elephant poaching in Africa. British Journal of Criminology, 49, 451-471.

LøKKEвORG, S. (2003) Review and evaluation of three mitigation measures-bird-scaring line, underwater setting and line shooter-to reduce seabird bycatch in the north Atlantic longline fishery. Fisheries Research, 60, 11-16.

Melvin, E.F., Guy, T.J. \& Read, L.B. (2010) Shrink and defend: a comparison of two streamer line designs in the 2009 South Africa tuna fishery. Report to the Third Meeting of the Seabird Bycatch Working Group, Agreement on the Conservation of Albatrosses and Petrels, SBWG-3 Doc 13, Mar del Plata, Argentina.

Nel, D.C., Ryan, P.G. \& Watkins, B.P. (2002) Seabird mortality in the Patagonian toothfish longline fishery around the Prince Edward Islands, 1996-2000. Antarctic Science, 14, 151-161.

NeL, D.C. \& TAYLOR, F.E. (2003) Globally Threatened Seabirds at Risk from Longline Fishing: International Conservation Responsibilities. BirdLife International Seabird Conservation Programme, Stellenbosch, South Africa.

Pauly, D. \& Zeller, D. (eds) (2015) Sea Around Us Concepts, Design and Data. Http://www.seaaroundus.org [accessed July 2016].

Petersen, S.L., Honig, M. \& NeL, D.C. (2007) The Impact of Longline Fisheries on Seabirds in the Benguela Current Large Marine Ecosystem. SCRS/2007/026. International Convention for the Conservation of Atlantic Tunas.

Petrossian, G.A. (2015) Preventing illegal, unreported and unregulated (IUU) fishing: a situational approach. Biological Conservation, 189, 39-48.

Petrossian, G.A. \& Clarke, R.V. (2014) Explaining and controlling illegal commercial fishing: an application of the CRAVED theft model. British Journal of Criminology, 54, 73-90.

Pires, S.F. \& Clarke, R.V. (2011) Sequential foraging, itinerant fences and parrot poaching in Bolivia. British Journal of Criminology, 51, 314-335.

Pires, S.F. \& Clarke, R.V. (2012) Are parrots CRAVED? An analysis of parrot poaching in Mexico. Journal of Research in Crime \& Delinquency, 49, 122-146.

Pitcher, T., Kalikoski, D. \& Pramod, G. (2006) Evaluations of Compliance with the FAO (UN) Code of Conduct for Responsible Fisheries. University of British Columbia, Fisheries Centre, Vancouver, Canada.

Prince, P.A., Croxall, J.P., Trathan, P.N. \& Wood, A.G. (1998) Pelagic distribution of South Georgia albatrosses and their relationships with fisheries. In Albatross Biology and Conservation (eds R. Robertson \& R. Gales), pp. 137-167. Beatty and Sons, Chipping Norton, Australia.

Small, C.J. (2005) Regional Fisheries Management Organizations: Their Duties and Performance in Reducing Bycatch of Albatrosses and Other Species. BirdLife International, Cambridge, UK.

Sumaila, U.R., Alder, J. \& Keith, H. (2006) Global scope and economics of illegal fishing. Marine Policy, 30, 696-703.

Thomas, R. (2000) Longlining: a major threat to the world's seabirds. World Birdwatch, 22, 8-11.

Tuck, G.N., Polacheck, T. \& Bulman, C.M. (2003) Spatio-temporal trends of longline fishing effort in the Southern Ocean and implications for seabird bycatch. Biological Conservation, 114, 1-27.

Weimerskirch, H., Brothers, N. \& Jouventin, P. (1997) Population dynamics of wandering albatross Diomedea exulans and Amsterdam albatross D. amsterdamensis in the Indian Ocean and their relationships with long-line fisheries: conservation implications. Biological Conservation, 79, 257-270.

Weimerskirch, H., Delord, K., Guitteaud, A., Phillips, R.A. \& Pinet, P. (2015) Extreme variation in migration strategies between and within wandering albatross populations during their sabbatical year, and their fitness consequences. Scientific Reports, 5, http://dx. doi.org/10.1038/srepo8853.

Xeno-Canto (2015) Sharing bird sounds from around the world. Http://xeno-canto.org [accessed July 2015]. 
Žydelis, R., Lewison, R.L., Shaffer, S.A., Moore, J.E., Boustany, A.M., Roberts, J.J. et al. (2011) Dynamic habitat models: using telemetry data to project fisheries bycatch. Proceedings of the Royal Society B: Biological Sciences, 278, 3191-3200.

\section{Biographical sketches}

Gohar A. Petrossian applies criminological theories, in particular environmental criminology and opportunity theories, to study illegal, unreported and unregulated fishing and related crime problems. Ro LF A. DE BY's research interests include developing large-scale applications of spatial data in the context of societal problem solving in developing countries, especially in the domains of rural development, agriculture and conservation. RONALD V. CLARKE is an expert on situational crime prevention, the science of reducing opportunities for crime. He has applied this approach to poaching of African elephants, tigers in Indian reserves, and parrots in the Neotropics, as well as to illegal fishing. 